\title{
Nikolaj Mihajlov (Nikolai Mikhailov)
}

\section{7-2010}

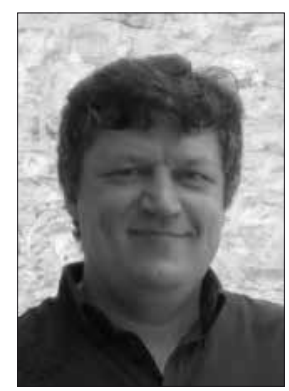

V torek, 25. maja 2010, je v Vidmu (Udine) na pragu svojega 43. rojstnega dne rojen je bil 11. junija 1967 v Moskvi - nepričakovano sklenil svojo življenjsko pot baltist in slavist Nikolaj Mihajlov (Nikolai Mikhailov).

Nikolaj Mihajlov spada v plejado tistih ruskih znanstvenikov (Aleksander Vostokov, Izmail Sreznjevski, Nestor Petrovski, Aleksej Haruzin, Jevgenija Linjova, Iskra Čurkina, Ljubov Kurkina), ki so pomembno prispevali k raziskavam slovenske kulturne in jezikovne dediščine. Po osnovni izobrazbi je bil klasični filolog, toda izjemna nadarjenost za jezike (obiskoval je desetletko z ruskim in francoskim učnim jezikom) in neizmerna zakladnica znanja, ki mu jo je nudilo domače okolje (mama - vidna ruska filologinja Tatjana Vladimirovna Civjan - in družina velikana ruske filologije, akademika Vladimira Nikolajeviča Toporova), sta ga pripeljali v baltoslovansko filologijo in mitologijo.

Po krajšem podiplomskem študiju na Inštitutu za slavistiko in balkanistiko pri akademiku Nikiti Tolstoju ga je življenjska pot leta 1990 vodila v Italijo, kjer je najprej poučeval ruščino na različnih jezikovnih tečajih $\mathrm{v}$ Bolzanu in Trentu, $\mathrm{v}$ letih 1992-1998 pa je deloval kot lektor za ruski jezik na Univerzi v Pisi, v letih 1993-1995 tudi kot docent za ruski jezik na Univerzi v Trentu. V letih 1995-1998 je zažarel kot meteor na slavističnem in baltističnem nebu. Skupaj s Pietrom Dinijem je v Pisi v letih 1995-2003 izdal devet letnikov baltističnega zbornika Res Balticae, sam pa v Madridu leta 1998 knjigo Baltische und Slawische Mythologie. Za doktorski študij na univerzi v Leidnu (Nizozemska) si je izbral jezikoslovno analizo slovenskih jezikovnih spomenikov od 14. stoletja do Trubarja; promoviral je leta 1998. Njegov promotor je bil ugledni nizozemski slavist Frederik Kortlandt. 
Knjiga Frühslowenische Sprachdenkmäler: die handschriftliche Periode der slowenischen Sprache (XIV. Jh. bis 1550) je izšla v Amsterdamu in Atlanti (GA) leta 1998, močno skrajšani slovenski prevod Jezikovni spomeniki zgodnje slovenščine pa v Trstu leta 2001. Knjiga, predvsem 450 strani obsegajoči nemški izvirnik, je doživela številne ugodne ocene $\mathrm{v}$ najuglednejših slavističnih revijah sveta, saj je bila z njo zapolnjena zevajoča vrzel $v$ jezikoslovnih obravnavah zgodovine slovenskega jezika. Mihajlov je leta 1998 postal izredni profesor na univerzi v Vidmu in bil v študijskem letu 1999/2000 predstojnik katedre za slovenistiko. Krajši čas je predaval tudi na univerzah $\mathrm{v}$ Veroni in Ljubljani.

Kot učenec ruske mitosemiotične šole V. N. Toporova se je Mihajlov z veliko vnemo posvečal tudi raziskavam na področju baltske in slovanske mitologije, zlasti na litovskem in slovenskem gradivu. V letih 1985-1990 je sodeloval na raziskovalnih taborih, ki jih je na litovskem podeželju organizirala Vilenska univerza, v letih 1988-1990 pa je pri litovskem veleposlaništvu v Moskvi soorganiziral tečaje litovskega jezika in na njih tudi predaval. Litovščino in slovenščino je obvladal kot redkokateri tujec, Litovci pa so mu za zasluge v baltistiki podelili litovsko državljanstvo.

Pri Slovencih je odločilno spodbudil zanimanje za poglobljeno raziskovanje domačega mitološkega izročila $\mathrm{v}$ slovanskem kontekstu in za izjemni znanstveni opus V. N. Toporova. Na njegovo pobudo je leta 1998 v Ljubljani in Pisi začela izhajati mednarodna znanstvena revija Studia mythologica Slavica (od leta 2000 izhaja v Ljubljani in Vidmu), katere sourednik je bil skupaj z Moniko Kropej z Inštituta za slovensko narodopisje ZRC SAZU v Ljubljani. Doslej je izšlo že trinajst letnikov. Z njegovim posredovanjem je na Oddelku za etnologijo in kulturno antropologijo Filozofske fakultete Univerze v Ljubljani leta 2002 izšel (fragmentarni) slovenski prevod knjige V. N. Toporova Predzgodovina književnosti pri Slovanih: poskus rekonstrukcije. Istega leta je v Trstu izšla knjiga N. Mihajlova Mythologia Slovenica: poskus rekonstrukcije poganskega izročila pri Slovencih.

Nikolaj Mihajlov je avtor več kot 150 znanstvenih in strokovnih publikacij s področij slovanske in baltske mitologije, baltistike, klasične filologije in slovenistike, objavljenih v različnih evropskih jezikih.

Presenetljivo je, da je prav Nikolaj Mihajlov in ne kdo od Slovencev sestavil italijansko-slovenski in slovensko-italijanski žepni slovar, ki je v Milanu v letih 1996-2008 izšel v kar sedmih izdajah.

$\mathrm{S}$ svojimi deli se je za vedno vpisal v zgodovino slavistike in baltistike, $\mathrm{s}$ svojim osebnim šarmom pa tudi v srca vseh, ki smo ga osebno poznali.

Italijanski in slovenski kolegi in prijatelji smo se od Nikolaja poslovili 29. maja $\mathrm{v}$ cerkvi glavnega pokopališča $\mathrm{v}$ Vidmu, njegovi ruski in litovski kolegi in sorodniki pa teden dni pozneje na Vagankovskem pokopališču v Moskvi. Mami Tatjani Vladimirovni Civjan, ki ji je usoda namenila eno najhujših preizkušenj, kar jih lahko doživi mati, izrekam v svojem in v imenu slovenskih kolegov tudi ob tej priložnosti svoje najgloblje sožalje.

\section{Silvo Torkar}




\section{Izbor iz bibliografije}

\section{Knjige}

Mitologia slava: studi sulla mitologia dei popoli slavi: antologia, uvod in ur. N. Mikhailov, Pisa: ECIG, 1993.

Mitologia baltica: studi sulla mitologia dei popoli baltici: antologia, ur. Pietro U. Dini - Nikolai Mikhailov, Pisa: ECIG, 1995.

Dizionario italiano-sloveno, sloveno-italiano, Milano: Vallardi, 1996, ${ }^{7} 2008$.

I monumenti linguistici sloveni dell'epoca dei manoscritti: lingua e letteratura slovena dai Monumenti di Frisinga a P. Trubar: con una nuova edizione del manoscritto di Cergneu, Pisa: ECIG, 1997.

Baltische und slawische Mythologie: ausgewählte Artikel, Madrid: Actas, 1998 (Studia mythosemeiotica 1).

Frühslowenische Sprachdenkmäler: die handschriftliche Periode der slowenischen Sprache (XIV. Jh. bis 1550), Amsterdam - Atlanta (GA): Rodopi, 1998 (Studies in Slavic and General Linguistics 26).

Vladimir Toporov, Baltu mitologijos ir ritualo tyrimai, izbor Nikolai Mikhailov, Vilnius: Aidai, 2000.

Jezikovni spomeniki zgodnje slovenščine: rokopisna doba slovenskega jezika (od XIV. stol. do leta 1550), Trst: Mladika - Knjižnica Dušana Černeta, 2001.

Mythologia Slovenica: poskus rekonstrukcije slovenskega poganskega izročila, Trst: Mladika - Knjižnica Dušana Černeta, 2002.

\section{Razprave in članki}

Appunti su *Belobog e *Černobog, v: Ricerche slavistiche 41 (1994), 41-51.

$\mathrm{K}$ реконструкции отдельных фрагментов славянской космологии на основе фольклорных источников, Книжевна историја 26 (1994), št. 94, 325-337.

Еше раз о *Белобоге и *Чернобоге: к возможности привлечения некоторых косвенных источников), Славяноведение 1995, št. 3, 89-96.

Das »gemischte« slawisch-baltische Pantheon von Christian Knauthe, Res Balticae (Pisa) 1 (1995), 115-139.

Lett. nāve, lit. novis, altslaw., altruss. *nav̌ u. a.: zum Problem der Realisierung eines balto-slawischen (Ur)stammes auf der mythologischen Ebene, PontoBaltica 6 (1995), 95-102.

Baltico-slovenica: alcuni paralleli mitologici, v: Res Balticae 2 (1996), 151-178.

К реконструкции отдельных космогонических / космологических и антропологических фрагментов славянской модели мира на материале русских заговоров, v: Studies in Slavic Folklore and Folk Culture 2, Oakland (CA), 1997, 57-76.

Eine slowenisch-prußische lexikalisch-mythologische Parallele: kres/kresze, Slovenski jezik - Slovene Linguistic Studies 1 (1997), 153-159.

Materiali preliminari per una bibliografia della mitologia baltica (1900-1996), v: Res Balticae 3 (1997), 165-213.

Kr(e)snik, eine Figur der slowenischen Version des urslawischen Hauptmythos, Книжевна историја 29 (1997), št. 101, 23-37. 
Vieno šaltinio lingvistinès-mitologinès reabilitacijos klausimu: Jono Lasickio $» D e$ Diis Samagitarum«, Naujasis židinys-Aidai (Vilnius) 1997, št. 11-12, 449454.

Baltoslovanska mitologija - baltska in slovanska mitologija - slovenska mitologija: nekaj terminoloških opomb, Traditiones 26 (1997), 77-99.

O роли словенского языка в Бенечии на рубеже XV-XVI вв.: к 500-летию первой словенской записи Чернейской рукописи, Слово и культура I: памяти Никиты Ильича Толстого, Москва: Индрик, 1998, 143-160.

Baltische Mythologie: der aktuelle Zustand der Forschung: Probleme und Perspektiven, v: Baltistik: Aufgaben und Methoden, ur. A. Bammesberger, Heidelberg: Universitätsverlag Carl Winter, 1998 (Indogermanische Bibliothek 19), 409-416.

Еще раз об одном трактате по литовской мифологии (Попытка реабилитации труда Яна Ласицкого о жемайтских богах), v: Подvтролоv к 70-летию Владимира Николаевича Топорова, Москва: Индрик, 1998, 428-438.

Eines der ersten slowenischen Sprachdenkmäler: Klagenfurter Handschrift (Celovški/Rateški rokopis), XIV. Jh., Ponto-Baltica 7 (1997), 129-161.

Словенские числительные в »Рукописи из Удине« (1458), v: Славянские этюды: сборник к юбилею С. М. Толстой, ur. Е. Е. Левкиевская, Москва: Индрик, 1999, 279-285.

Балтийские боги в сербо-лужицком пантеоне А. Френцеля, v: Балто-славянские исследования 1997, Москва, 1998, 392-399.

Die sogenannte »slowenische Homilieskizze« (»Slovenski načrt za pridigo«) aus der handschriftlichen Periode der slowenischen Sprache, Slovenski jezik Slovene Linguistic Studies 2 (1999), 77-90.

Edition der Handschrift mit slowenischen Monatsnamen (1466) aus Škofja Loka, v: Поэтика. История литературы. Лингвистика = Essays in Poetics, Literary History and Linguistics: сборник к 70-летию Вячеслава Всеволодовича Иванова, Москва: ОГИ, 1999, 619-625.

Epitetni pomen slovanskih poganskih teonimov kot morebitna razlaga polikefalnosti nekaterih božanstev (še enkrat o rekonstrukciji slovanske mitologije), Traditiones 28 (1999), št. 1, 179-183.

Einige Anmerkungen zum Begriff »baltisch-slawische« Mythologie, v: Aspekte baltischer Forschung: R. Eckert zum 65. Geburtstag, ur. J. D. Range, München - Greifswald, 2000, 206-225.

»Запад на Балканах« или »балканский запад« в лингвистическом аспекте: далматинский язык, v: Восток и Запад в балканской картине мира: памяти Владимира Николаевича Топорова, Рос. акад. наук, Ин-т славяноведения, ur. odbor T. Н. Свешникова - И. А. Седакова - Т. В. Цивьян, Москва: Индрик, 2007, 280-286.

Укр. мольфар, слвн. malavar и др.: демонологическая параллель, Terra Balkanica - Terra Slavica: балканские чтения 9: К юбилею Т. В. Цивьян, ur. odbor Т. М. Николаева (odg. ur.) - И. А. Седакова - Т. Н. Свешникова, Москва: Ин-т славяноведени РАН, 2007, 93-97. 


\section{Uredniško delo}

Studi slavi, Pisa (Genova), 1993-1998 (skupaj z G. Dell'Agata, S. Garzoniom, P. U. Dinijem in J. Maruškovo)

Res Balticae: miscellanea italiana di studi baltistici, Pisa, 1995-2003 (skupaj s P. U. Dinijem).

Studia mythologica Slavica, 1998-2010, ZRC SAZU, Ljubljana - Dipartimento di Lingue e Civiltà Centro-orientali, Università degli Studi di Udine (skupaj z M. Kropej).

Балто-славянские исследования, Москва, 2004-2009. 